\title{
Purban Rice Farming (URF) as a Solution to the Gap Between Population Growth and Reduction of Farmlands Through Sustainable Development Goals for National Food Security
}

\author{
Neneng Nuryati \\ Banking Department \\ Polteknik Negeri Bandung \\ Bandung, Indonesia
}

\author{
Amar Sumarsa \\ Mathematics Department \\ Universitas Pakuan \\ Bogor, Indonesia
}

\author{
Edi Sagith \\ English Department \\ Sekolah Tinggi Ekonomi Manajemen Bisnis Indonesia (STEMBI) \\ Bandung, Indonesia
}

\begin{abstract}
The rate of world population growth is very extreme, while the rate of food supply has also dropped very sharply. The rate decline in food supply is compounded by a decline in farmlands. Cimahi is a small town in West Java experienced the something. Farmlands has changed its function into housing complexes, offices, malls, buildings causing a decline in farmlands. The remaining area of the rice field is only 152 hectares left which is a big problem for Cimahi. Gaps occur due to an explosion in population and a decrease in farmlands. Urban Rice Farming (URF) is a system of rice farming that is effective, efficient, innovative, unique, productive and is a solution. URF is a system of farming rice in poly bags with high productivity that can reach more than five times that of conventional rice fields. Other benefits are economic, cultural, social and educational benefits.
\end{abstract}

Keywords-URF, food, farmlands

\section{INTRODUCTION}

Indonesia is a rich country in natural and human resources, which has a high culture supported by perfect climates forming an agricultural culture. Agricultural culture is a great asset owned by Indonesia that should be carried on to make Indonesia the biggest agricultural country. One of the most important agricultural country's commodities is rice. Rice has a high strategic value and is the main food of Indonesia people that must get primary priority to make its people prosperous. Constructions and erections of buildings, housing complex, apartments, factories and lots more both compress out fertile rice fields and cause irony where a big agriculture country has to import rice from a small country such as Thailand and Vietnam. The decreased in rice production in Indonesia is caused by the excessive use of chemical fertilizers, pesticides, fungicides and herbicides.
In 1970 the advent of Green Revolution in Indonesia made the rice farmers increase their rice production and Indonesia was able to export rice to many countries. Unfortunately, having used the above chemicals for more than 45 years, all the rice fields in Indonesia have become dead soils so the rice production has decreased drastically. Consequently, almost all farmers have been living in poverty. They cannot send their children to high education. Young people are refused to be farmers because farming is not unpromising job anymore. Finally, many farmers have been selling their rice fields to housing developers. Then the rice fields have turned to housing complex, apartments and factories.

Researchers take some efforts to solve this problem. The solution is to develop new farmlands as said by Rejekiningrum [1]. In order to avoid gap between dramatically growth population and food (rice) supply then perfect plan to increase the growth of food (rice) production is absolutely urgent. Developing new farmlands needs a lot of fun and time. According to Ismet, if food availability is smaller than its needs, it can create a country's economic instability [2]. This instability could make various social and political upheavals occur. If food security is disrupted, then it can endanger national stability the unproductive lands potential to develop become a productive farmland by the system which is called Urban Rice Farming. This paper describes about URF in Cimahi that is a small city in West Java with very limited farmlands. In this research Urban rice farming is implemented by using poly bags as substitute of rice fields.

The purpose of this research is to increase rice production in limited land. 
Definition: Urban Rice Farming (URF) is a system of planting rice in polybags, in towns and big city, using with a big part of organic materials as a planting media, followed by applying extract organic fertilizers mixed with a little chemical fertilizer through the media to get abundant harvest.

Organic farming is an alternative agricultural system which originated early in the $20^{\text {th }}$ century in reaction to rapidly changing farming practice, Organic farming is as a method of crop and livestock production that involves much more than choosing not to use pesticides, chemical fertilizer, genetically modified organisms, antibiotic, and growth hormones [3].

Urban Rice Farming is an effective and efficient as well as sustainable solution without requiring wide lands and fertile soils, without irrigation, without cultivation and without digging the weeds and without mud that impresses a dirty job to the youth. Urban Rice Farming is expected to bring the agricultural culture back in our society, especially in Cimahi.

\section{A. Benefits of URF}

The economic benefit is as follows:

The increase in significant productivity may increase the ability of farmers' economy effecting on purchasing power, and competing power [3]. The corrected purchasing power Will encourage industrial growth of goods and service. Thus improving the economic welfare.

1) Other benefits: URF will raise the name of Cimahi City and make it famous nationally and internationally through the National Record and the World Record for the Most Urban Rice Farming in poly bags, the Most saplings of rice, the Most panicles of rice per poly bag and the Highest production of rice through Museum Record lndonesia (MURI) /Indonesia Record Museum.

2) Social benefit: The appeal of URF will attract young people's interest to grow rice and give prestige so farming rice will not be considered to be an inferior job anymore. Employment will be widely open and bear young entrepreneurs in the field of agriculture.

3) Cultural benefit: Ancient culture supported by natural and human resources, as well as agricultural culture will be alive again and sustainable. As the return of the agricultural culture, cooperation among people, cross- tribal tolerance, living together in harmony will color people's lives and living.

4) Environmental benefit: Throwing rubbish and garbage around is considered normal by many people is something to be changed. The mindset and mental attitude should be changed by productive, innovative and creative attitudes. Urban Rice Farming will need a lot of organic materials for growing media coming from Organic wastes which have long been the town and city problem. By doing the URF, people will recycle and use the organic materials for growing media so the Environment will be kept clean and healthy. There fore, the citizens will care about their Environment

\section{METHOD OF URBAN RICE FARMING}

- Pour a polybag within $20 \%$ of soil, $40 \%$ compost (bokashi), 30\% rice husk, $10 \%$ ESSA organic fertilizer

- Put padi seeds in warm water for 24 hours then wrap with cotton material until they germinate.

- Plant 1-3 seeds in the media and water twice a day in the morning and in the afternoon in the middle of media.

- Two weeks after planting, fertilize the young rice plants by ESSA Extract organic fertilizer mixed with a little NPK fertilizer. Dissolve them with fresh water thoroughly.

- 30 and 45 days after planting fertilize again the rice plants as instructed above in double dosage. Materials used for URF are mostly organic wastes from houses, traditional markets, restaurants, culinary industries, and animal farms. The uses of organic wastes will automatically reduce the waste volume that pollute environment. This corresponds with Go Green Program that is Reuse, Reduce, Recycle.

\section{RESULTS}

- One polybag contains 82 saplings, 60 panicle of rice, 720 grains of rice.

- One polybag produces $0,6 \mathrm{~kg}$.

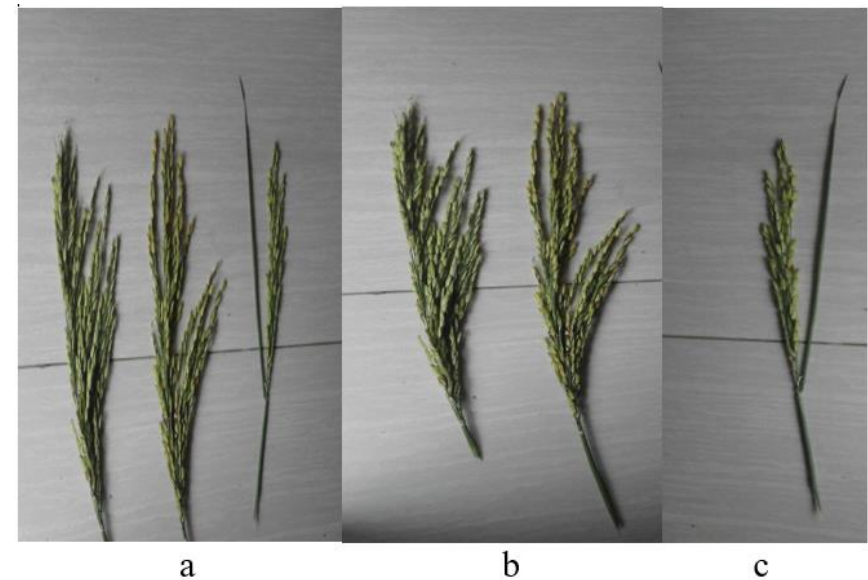

Fig. 1. Comparison of the results of rice grains.

Figure 1. (a) shows comparison of the results of rice grains fertilized with organic and non-organic fertilizers. Figure 1. (b) shows the grain produced using in organic fertilizers rice. Figure 1. (c) shows the grain produced using non-organic fertilizers. From those figure it can be concluded that by using organic fertilizer rice plants produce more grain than rice using non-organic fertilizer. In addition to more rice grains, the land for agriculture will also be better and maintain fertility because the soil does not become damaged.

Farmlands of Cimahi showed in Figure 2 as follow. 


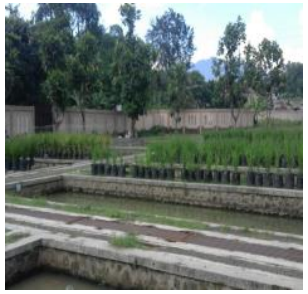

A

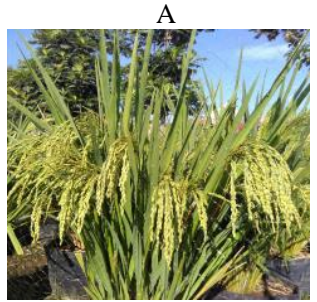

E
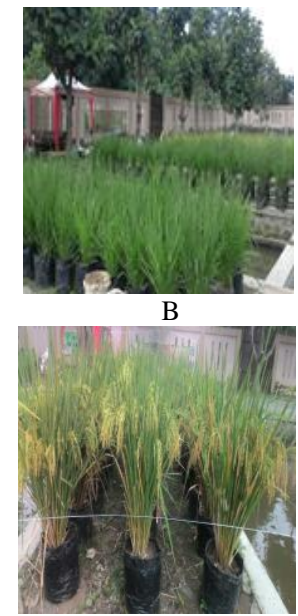

F

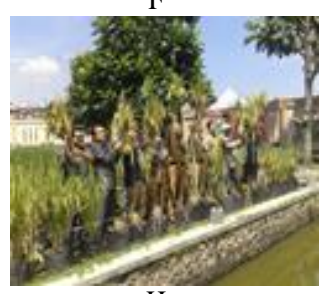

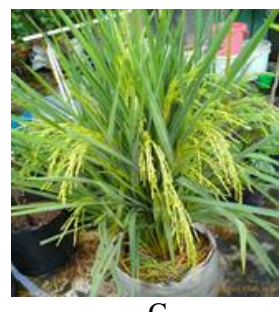

$\mathrm{C}$

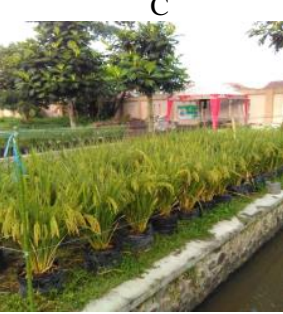

G

Fig. 2. Rice planting.

\section{A. Cimahi Town}

Cimahi is a small town with three districts having only 132 hectares of farmlands left also has the same problem like other towns and rural areas. It is impossible to build or make new rice fields and bring the agricultural culture back to this town. According to Growth Population in Indonesia, population of Cimahi will be the same. A Little town Cimahi as a part of Indonesia has a same growth as is figured out in Table 2.

TABLE I. CIMAHI PopUlation 2003-2014

\begin{tabular}{|l|l|}
\hline \multicolumn{1}{|c|}{ Year } & Population \\
\hline 2003 & 483.242 \\
\hline 2004 & 496.060 \\
\hline 2005 & 509.189 \\
\hline 2006 & 522.731 \\
\hline 2007 & 536.743 \\
\hline 2008 & 551.216 \\
\hline 2009 & 566.220 \\
\hline 2010 & 541.177 \\
\hline 2011 & 553.593 \\
\hline 2012 & 562.297 \\
\hline 2013 & 570.991 \\
\hline 2014 & 579.015 \\
\hline
\end{tabular}

The growth population increases dramatically in Cimahi, farmlands decrease vice versa. It happened caused by land conversion function. Rice farming land is less every year decreased by housing complex, malls, offices. In other side the need of food increases rapidly. One person needs $0,54 \mathrm{~kg}$ of rice a day, 194,4 kg annually. Population of Cimahi $2010-$ 2014 showed in Figure 3.

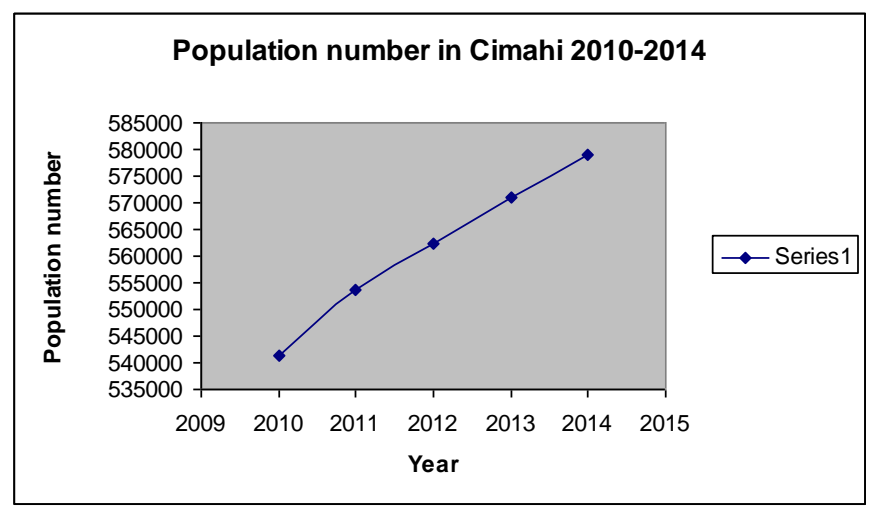

Fig. 3. Population number in Cimahi 2010 - 2014.

Figure 3 showed significance of population growth 2010 2014 the average rate of growth 9459,5 people annually. Applying regression model resulted prediction annually rate of population growth in Cimahi is 9307,4 personThus it can be predicted that in 2020 the population of Cimahi will be around 635873,8 people. It occured from trend linearly regresion $\mathrm{Y}=$ $561414,6+9307,4 \mathrm{t}$

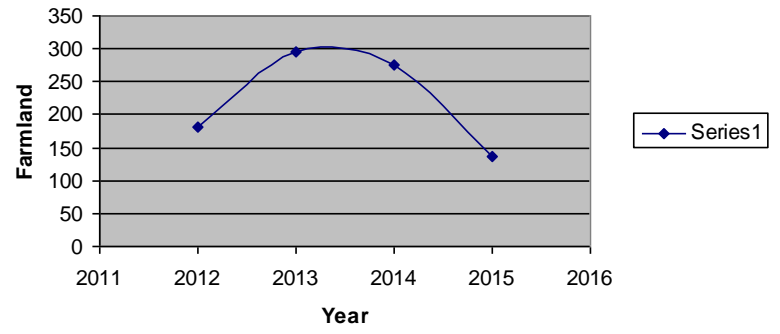

Fig. 4. Showed the decline of farmlands in Cimahi town.

Figure 4 shows a decrease in agricultural land in the city of Cimahi. This land decline follows the quadratic trend of $\mathrm{Y}=$ $10.61 \mathrm{t} 2-5.34 \mathrm{t}+328$. Looking at the trend of squares for agricultural land that has decreased drastically, the agricultural land in Cimahi, predicted for 2020 will greatly decrease, namely $-1825,362$ which means there is no more agricultural land in Cimahi. With the absence of agricultural land, there is no rice farming.

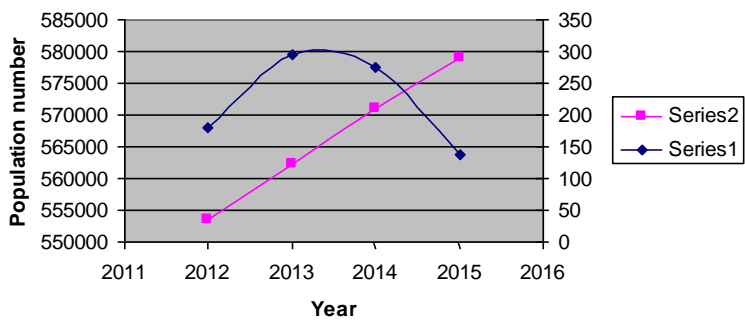

Fig. 5. Diagram land area and population Number.

Analyzing Figure 3 and Figure 4 there is an extreme rate. Extreme growth of population and extreme reduction of farmlands. These condition produce a gap. The solution of that problems is urban rice farming because URF a system of farming on a limited land. 


\section{DISCUSSION}

The Comparation rice yield between 1 hectare of conventional rice field and Urban Rice Farming in poly bags. 1 hectare of rice field contains 160,000 rice plants producing about 4-5 tons of paddy per season, whereas 1 hectare of Urban Rice Farming in poly bags contains 100,000 rice plants in poly bags producing between 40 and 50 tons of paddy per season. So Urban Rice Farming in poly bags can produce ten times more crops than growing rice in conventional rice field. Besides, growing rice in poly bags can make use of unproductive lands in the cities, in the towns, in borders, and even in the refugee shelters. Moreover, Urban Rice Farming in poly bags doesn't need very expensive irrigation, cultivation, pulling the weeds, much water and so on. Last but not the least, Urban Rice Farming in poly bags will never destroy soil, microorganism and pollution ground water and the product is health food as it makes use of organic wastes from homes, traditional markets, catering and culinary industries, dry leaves in the streets and lots more.

\section{CONCLUSION}

Urban rice farming is a unique system because no other planting rice in polybag system produced rice grains, panicles, as much as Urban Rice Farming system. URF is an innovative and prospective system to solve food adequacy problem in the future.

\section{REFERENCES}

[1] P. Rejekiningrum, Rice Surplus Optimization Model to determine National Food Security, Proceedings of the National Seminar on Mathematics, Science and Technology, 2013.

[2] M. Ismet, Challenges in Realizing a Strong Food Policy, Food, 2007.

[3] C. Youngsang, JADAM Organic Farming: ULTRA Powerful Pest and Disease Control Solution, Make all-Natural Pesticide, The way to UltraLow-Cost agriculture! 1st edition, 2006. 